\title{
Using Fuzzy Game Theory on IPO'S Pricing Behavior
}

\author{
Kuang-Hua Hsu ${ }^{1}$ Jian-Fa $\mathrm{Li}^{2}$ Hon-Jenq Fan ${ }^{3}$ \\ ${ }^{1}$ Department of Finance, Chaoyang University of Technology, E-mail: khhsu@mail.cyut.edu.tw \\ ${ }^{2}$ Department of Finance, Chaoyang University of Technology,Taichung County, Taiwan, R. O. C., \\ E-mail: jfli@cyut.edu.tw \\ ${ }^{3}$ Department of Finance, Chaoyang University of Technology, E-mail: fanalley0311@yahoo.com
}

\begin{abstract}
The purpose of this research is to explore the IPO pricing behavior in an underwriting system by applying the fuzzy game theory. Results of this study are: (1) The application of the fuzzy game theory is more consistent with the uncertainty relationship of human interference between independent and dependent variables in practice with profit return function as a potential function. Rewards for underwriters can be judged according to the principle of experience, which copes with actual situations more properly. (2) Differences of satisfaction exist between underwriters and issuing companies for IPO pricing in the underwriting system. Profit or satisfaction exchange can be conducted appropriately during the process of negotiating offering prices. (3) The comparison of profit changes and satisfaction sensitivity between underwriters and issuing companies can be served as a reference of exchange and increase in satisfaction for underwriters and issuing companies
\end{abstract}

Keywords: Pricing behavior; Underwriting system; IPO; Fuzzy game theory

\section{Introduction}

The initial public offerings (IPO) have been well documented. Based on practical operations the way to calculate a reasonable offering price has not yet been reached. One of the potential reasons is that the offering price evaluation model currently applied is not ideal as the existing relevant evaluation approaches. In fact, offering prices are determined through negotiation between underwriters and issuing companies (Ljungqvist and Wilhelm, 2003). The purpose of this research is to apply and extend the fuzzy game theory to an IPO pricing process.

\section{The Model}

The total subscription number was a reciprocal of the offering price. Thus, the actual subscription number is as follow:

$$
L Q=\frac{\left(Q_{s}-Q_{u}\right)}{\widetilde{A}}
$$

$Q_{s} \quad$ total underwriting quantity; $Q_{u}$ underwriter subscription quantity; $\widetilde{A}$ fuzzy number of odds of lottery

The interval of odds of lottery $\widetilde{A}$

$$
\begin{aligned}
& \text { is }(\widetilde{A})_{\alpha}=\left\lfloor(\widetilde{A})_{\alpha}^{L},(\widetilde{A})_{\alpha}^{R}\right\rfloor(\widetilde{d})_{\alpha}=\left\lfloor(\widetilde{d})_{\alpha}^{L},(\widetilde{d})_{\alpha}^{R}\right\rfloor \\
& (\widetilde{e})_{\alpha}=\left\lfloor(\widetilde{e})_{\alpha}^{L},(\widetilde{e})_{\alpha}^{R}\right\rfloor \cdot \widetilde{d}, \widetilde{e} \text {. The fuzzy function of }
\end{aligned}
$$

the odds of lottery can be shown

as: $\widetilde{A}=-\widetilde{d} \times \frac{M-p}{M}+\widetilde{e} \cdot \widetilde{A}$ fuzzy number of odds

of lottery; $\frac{M-p}{M}$ discounted rate of offering price;

$\widetilde{P}$ : fuzzy number of offering price; $M$ fair market

price; $\widetilde{e}, \widetilde{d}$ fuzzy parameter; Revenues from

subscription processing fees by drawing of lots for

underwriters are expressed as:

$U L=17.5 \times \frac{\left(Q_{s}-Q_{u}\right)}{-\widetilde{d} \times \frac{M-P}{P}+\widetilde{e}} ; \frac{M-p}{M}$ discounted rate of

offering price; $M$ fair market price; $\widetilde{e}, \widetilde{d}$ fuzzy

parameters; $Q_{s} \quad$ total underwriting number; $Q_{u}$

underwriter subscription quantity. Capital gains from 
subscribed shares by underwriters equal subscription number multiply the difference between offered stock price and offering price.

$U C=Q_{u} \times(M-P) ; Q_{u} \quad$ subscription quantity by underwriter; $M$ fair market price; $P$ offering price;

The profit function $\left(\pi_{u}\right)$ of the underwriters is as equation (2) :

$\pi_{u}=U P+U L+U C=\left[-\widetilde{a} \times\left(P \times 1000 Q_{s}\right)+\tilde{b}\right] \times P \times 1000 Q_{s}+17.5 \times \frac{\left(Q_{s}-Q_{u}\right)}{-\widetilde{d} \times \frac{M-P}{P}+\widetilde{e}}+Q_{u} \times(M-P)+K$ s.t. $Q_{s} \leq Q_{u} ; \quad M \geq P \geq 10$

$Q_{u} \quad$ number of subscribed shares; $Q_{s}$ number of underwriting shares in proportion to underwriting rate; $M \quad$ fair market price; $P$ offering price; $K$ commission revenue of fixed constant. The constraint $M \geq P \geq 10$ means when market price is lower than offering price, underwriters will subscribe shares to prevent from capital loss. The profit function of public companies $\left(\pi_{c}\right)$ is as equation (3) :

$\pi_{c}=(M-10) \times\left(Q_{a l}-Q_{s}\right) \times 1000+(P-10) \times Q_{s} \times 1000 \quad-\left[-\tilde{a} \times\left(P \times 1000 Q_{s}\right)+\tilde{b}\right] \times P \times 1000 Q_{s}-c$

(3)

$Q_{\text {all }} \quad$ total number of issuance; $Q_{s}$ number of underwriting shares in proportion to underwriting rate; $M$ fair market price; $P$ offering price; c other fixed expenses.

In a cooperative game, the united profit of public companies and the underwriters is the sum of profits on both sides.
Max $\pi_{c}+\pi_{u}=(M-10) \times\left(Q_{\text {all }}-Q_{s}\right) \times 1000+(P-10) \times Q_{s} \times 1000-c+17.5 \times \frac{\left(Q_{s}-Q_{u}\right)}{-\widetilde{d} \times \frac{M-P}{P}+\widetilde{e}}+Q_{u} \times(M-P)+\mathrm{k}$

s.t. $Q_{s} \leq Q_{u} \quad M \geq P \geq 10 ; Q_{\text {all }}$ total number of issuance; $Q_{s}$ number of underwriting shares in proportion to underwriting rate; $M$ fair market price; $P$ offering price; c other fixed expenses; $K$ commission revenue of fixed constant. The fuzzy number of the united profit is $\left\lfloor(\widetilde{d})_{\alpha}^{L},(\widetilde{d})_{\alpha}^{R}\right\rfloor\left\lfloor(\widetilde{e})_{\alpha}^{L},(\widetilde{e})_{\alpha}^{R}\right\rfloor$ and shown as $\alpha$-cut.

Max $\pi_{c}+\pi_{u}=(M-10) \times\left(Q_{a l}-Q_{s}\right) \times 1000+(P-10) \times Q_{s} \times 1000-c+17.5 \times \frac{\left(Q_{s}-Q_{u}\right)}{-(\widetilde{d})_{a}^{L} \times \frac{M-P}{P}+(\widetilde{e})_{a}^{U}}+Q_{u} \times(M-P)+K$

The maximum and minimum profit functions for underwriters and public companies are as follow:

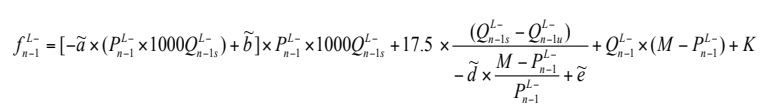

If the maximum profit function of an underwriter is:

$f_{n}^{L^{*}}=\left[-\widetilde{a} \times\left(P_{n}^{L^{*}} \times 1000 Q_{n s}^{L^{*}}\right)+\widetilde{b}\right] \times P_{n}^{L^{*}} \times 1000 Q_{n}^{L^{*}}+17.5 \times \frac{\left(Q_{n s}^{L^{*}}-Q_{n u}^{L^{*}}\right)}{-\widetilde{d} \times \frac{M-P_{L^{*}}^{L^{*}}}{P_{n}^{L^{*}}}+\widetilde{e}}+Q_{n}^{L^{*}} \times\left(M-P_{n}^{L^{*}}\right)+K$

The optimum solution of the maximum limitation and the minimum goal of Zadeh (1965) is expressed as :

$$
F G_{\max \min }=\operatorname{Max} \mu_{\mathrm{FG}}(P)=\operatorname{Max}\left[\mu_{C}(p) \wedge \mu_{G}(p)\right]
$$

The best combination is to locate $\operatorname{Max} \operatorname{Min}(\alpha, \beta)$.

Now, if $\lambda=\min (\alpha, \beta)$, then:

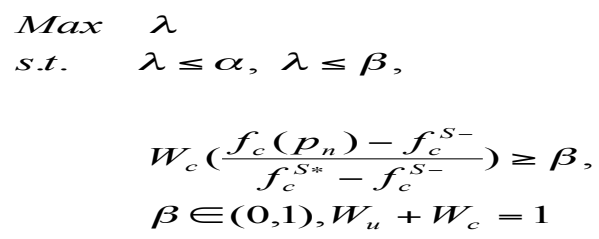

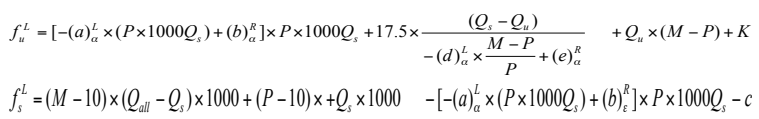




\section{Empirical Study}

The objects in this study are Company A, Company B and Company $\mathrm{C}$ and the $\alpha-c u t$ of $\mathrm{P} / \mathrm{E}$ approach (Table 1) revealed that underwriter handling fee revenue decreased as the fuzzy value $(\alpha)$ increased. An increase in $\alpha$ could result in increase in lottery odds, which not only renders a reduction in the total number of application offerings and processing fee revenue, and also a decrease in total underwriting profit. Table 2 shows the requirements for the least satisfaction, the issuing company would require sacrificing the underwriter's profit goal or make use of the fuzzy goals on both sides. When the least satisfaction level of Company A is 0.3887 and the profit satisfaction level is limited to $0.379,0.399$. As this is inconsistent with the satisfaction interval of the underwriter, the underwriter may accept reduced satisfaction to seek a more suitable profit satisfaction level for both parties (see Table 3).

Table $1 \alpha$ Value of Price/Earnings Ratio Approach - Company A

\begin{tabular}{|c|c|c|c|c|c|}
\hline$\alpha$ & $\begin{array}{l}\text { Offering } \\
\text { Price } \\
\text { (NT\$) }\end{array}$ & $\begin{array}{l}\text { Subscri } \\
\text { ptionN } \\
\text { umber } \\
\text { by } \\
\text { Under } \\
\text { writer }\end{array}$ & $\begin{array}{l}\text { Underwr Underwrit } \\
\text { iting er } \\
\text { HandlingHandling } \\
\text { Fee Fee } \\
\text { Revenue Revenue } \\
\text { (NT\$) (NT\$) }\end{array}$ & $\begin{array}{l}\text { Total Profi } \\
\text { of } \\
\text { Underwriter } \\
\text { (not including } \\
\text { subscription by } \\
\text { underwriter) } \\
\text { (NT\$) }\end{array}$ & $\begin{array}{l}\text { it Total } \\
\text { Profit } \\
\text { ofPubli } \\
\text { gc } \\
\text { y Compa } \\
\text { ny(NT\$ } \\
\text { ) }\end{array}$ \\
\hline 1 & 63.07 & 13,099 & $\begin{array}{l}15,610, \\
931\end{array}$ & $17,146,258$ & $\begin{array}{l}11,603, \\
848,69 \\
9\end{array}$ \\
\hline 0.8 & 63.07 & 13,099 & $\begin{array}{l}14,992, \\
143\end{array}$ & $16,507,740$ & $\begin{array}{l}11,604 \\
467,48 \\
7\end{array}$ \\
\hline 0.6 & 63.07 & 13,099 & $\begin{array}{l}14,373, \\
354\end{array}$ & $15,869,959$ & $\begin{array}{l}11,605 \\
086,27 \\
6\end{array}$ \\
\hline 0.4 & 63.07 & 13,099 & $\begin{array}{l}13,754, \\
566\end{array}$ & $15,232,877$ & $\begin{array}{l}11,605 \\
705,06 \\
4\end{array}$ \\
\hline 0.2 & 63.07 & 13,099 & $\begin{array}{l}13,135,960,6 \\
778\end{array}$ & $14,596,453$ & $\begin{array}{l}11,606, \\
323,85 \\
2\end{array}$ \\
\hline 0 & 63.07 & 13,099 & $\begin{array}{l}12,516,943,665 \\
990\end{array}$ & $13,960,654$ & $\begin{array}{l}11,606, \\
942,64 \\
0\end{array}$ \\
\hline
\end{tabular}

Table 2 Changes of the Optimum Price and the Max. Profit of Company A (Principle 1)

\begin{tabular}{|c|c|}
\hline Day 60 & \\
\hline$\beta$ Value & $\begin{array}{lc}\text { Profit } & \text { Membership Satisfaction } \\
\text { Change } & \text { for Change } \quad \text { for Change Ratio }\end{array}$ \\
\hline Underwriter & Both Parties Both Parties ( \\
\hline Public & $-\partial z_{2}\left(p, Q_{u}\right) /-\partial \mu_{2}\left(z_{2}\left(p, ! \delta=\Delta \mu\left(z_{1}\right) / \Delta\right.\right.$ \\
\hline Company & \\
\hline $0.3887 / 0.05$ & 0.0933 \\
\hline
\end{tabular}

\begin{tabular}{|c|c|c|c|}
\hline \multicolumn{4}{|l|}{49} \\
\hline \multicolumn{4}{|l|}{ Day 180} \\
\hline $\begin{array}{l}\beta \text { Value } \\
\text { Underwriter } \\
/ \\
\text { Public } \\
\text { Company }\end{array}$ & $\begin{array}{l}\text { Profit } \\
\text { Change for } \\
\text { Both Parties } \\
-\partial z_{2}\left(p, Q_{u}\right)\end{array}$ & $\begin{array}{l}\text { Membership } \\
\text { Change for } \\
\text { Both Parties } \\
-\partial \mu_{2}\left(z_{2}(p)\right.\end{array}$ & $\begin{array}{l}\text { Satisfaction } \\
\text { Change Ratio } \\
\text { ( } \\
\delta \delta=\Delta \mu\left(z_{1}\right) / \Delta\end{array}$ \\
\hline \begin{tabular}{|l}
$0.6 / 0.3792$ \\
\end{tabular} & 0.0771 & 1.0301 & 0.632 \\
\hline \begin{tabular}{|l|} 
Day 360 \\
\end{tabular} & & & \\
\hline $\begin{array}{l}\beta \text { Value } \\
\text { Underwriter } \\
/ \\
\text { Public } \\
\text { Company }\end{array}$ & $\begin{array}{l}\text { Profit } \\
\text { Change for } \\
\text { Both Parties } \\
-\partial z_{2}\left(p, Q_{u}\right)\end{array}$ & $\begin{array}{l}\text { Membership } \\
\text { Change for } \\
\text { Both Parties } \\
-\partial \mu_{2}\left(z_{2}(p)\right.\end{array}$ & $\begin{array}{l}\text { Satisfaction } \\
\text { Change Ratio } \\
( \\
\delta=\Delta \mu\left(z_{1}\right) / \Delta\end{array}$ \\
\hline $\begin{array}{l}0.3961 / 0.06 \\
72\end{array}$ & 0.0935 & 2.2952 & 0.1697 \\
\hline
\end{tabular}

Table 3 Changes of the Optimum Price \& the Max. Profit of Company A (Principle 2)

\begin{tabular}{|c|c|c|c|}
\hline \multicolumn{4}{|l|}{ Day 60} \\
\hline $\begin{array}{l}\beta \text { Value } \\
\text { Underwriter } \\
/ \\
\text { Public } \\
\text { Company }\end{array}$ & $\begin{array}{l}\text { Profit } \\
\text { Change for } \\
\text { Both Parties } \\
-\partial z_{2}\left(p, Q_{u}\right)\end{array}$ & \multicolumn{2}{|c|}{$\begin{array}{l}\text { Membership Satisfaction } \\
\text { or Change for Change Ratio } \\
\text { s Both Parties } \delta=\Delta \mu\left(z_{1}\right) / \Delta \\
/-\partial \mu_{2}\left(z_{2}(p, !\right.\end{array}$} \\
\hline $\begin{array}{l}0.3508 / 0.13 \\
72 \\
\end{array}$ & 0.0972 & 2.4243 & 03 \\
\hline \multicolumn{4}{|l|}{ Day 180} \\
\hline \begin{tabular}{|l}
$\beta$ \\
$\beta$ Value \\
Underwriter \\
$/$ \\
Public \\
Company \\
\end{tabular} & $\begin{array}{l}\text { Profit } \\
\text { Change for } \\
\text { Both Parties } \\
-\partial z_{2}\left(p, Q_{u}\right)\end{array}$ & \multicolumn{2}{|c|}{$\begin{array}{l}\text { Membership Satisfaction } \\
\text { or Change for Change Ratio } \\
\text { s Both Parties ( } \\
\text { ) }-\partial \mu_{2}\left(z_{2}\left(p, ! \delta=\Delta \mu\left(z_{1}\right) / \Delta\right.\right.\end{array}$} \\
\hline $0.6 / 0.3792$ & 0.0771 & 1.0301 & 0.632 \\
\hline \multicolumn{4}{|l|}{ Day 360} \\
\hline $\begin{array}{l}\beta \text { Value } \\
\text { Underwriter } \\
/ \\
\text { Public } \\
\text { Company } \\
\end{array}$ & \begin{tabular}{|l} 
Profit \\
Change for \\
Both Parties \\
$-\partial z_{2}\left(p, Q_{u}\right)$
\end{tabular} & $\begin{array}{l}\text { Membership } \\
\text { Change for } \\
\text { Both Parties } \\
-\partial \mu_{2}\left(z_{2}(p\right.\end{array}$ & $\begin{array}{l}\text { Satisfaction } \\
\text { Change Ratio } \\
( \\
\delta=\Delta \mu\left(z_{1}\right) / \Delta\end{array}$ \\
\hline $\begin{array}{l}0.3664 / 0.13 \\
10\end{array}$ & 0.0960 & 2.3566 & 0.3573 \\
\hline
\end{tabular}

\section{Conclusions}

The purpose of this study is to explore how to calculate the maximum profit and the optimum offering price or achieve the maximum profit goals for both parties through pricing models when the underwriter and the public company maintain a cooperative relationship. Profit functions of the underwriter and the public company are linear programmed and fuzzy variables are rationalized thru an interactive fuzzy game programming for the solutions to the maximum profit and the optimum offering price on both sides. Besides, both parties may exchange profits to promote satisfaction when the underwriter sets up the least satisfaction level. 


\section{References}

[1] N. Ichiro, and S. Masatoshi, S.,. “ Fuzzy cooperative games arising from linear production programming problems with fuzzy parameters,". Fuzzy sets and systems, 114, pp. 11-21, 2000.

[2] A.Ljungqvist, and W. J. Wilhelm, "IPO Pricing in the Dot-com Bubble,". Journal of Finance, 82 ,pp. 723-752, 2003.

[3] L.A. Zadeh, "Fuzzy Sets," Information and Control, 8, pp. 338-353, 1965. 